\title{
単軸引張りによって前ひずみを与えた黄銅板の降伏条件*
}

\author{
白鳥 英 亮** 池上 皓 三***
}

\section{The Yield Condition of the Brass Plate after its Uniaxial Prestraining}

by

\author{
Eiryo SHIRAToRI and Kozo Ikegami \\ (Tokyo Institute of Technology, Tokyo)
}

The applicability of Hill's anisotropic yield condition was studied experimentally for the anisotropic state given by uniaxial prestrain. The change of Hill's anisotropic constants with the increase of prestrain was investigated by the test of the small tensile specimens cut from the initially prestrained brass plate in various orientations to the initial prestraining direction. The subsequent yield surfaces after uniaxial prestraining and the necking angles of the small specimens were calculated by Hill's anisotropic constants and compared with the experimental results.

Hill's original expression of the anisotropic yield condition became a simpler form for the plate with the anisotropy given by the uniaxial prestrain. The calculated yield surfaces by this formula did not coincide well with the experimental values when the value of the subsequent yield stress in the initial prestraining direction was determined as that of the yield point in the reloading stress-strain diagram. But the coincidence between them became a little better when the applied stress value for the prestrain was adopted for the subsequent yield stress.

Hill's formula of the necking angle was found to be impertinent in instances where the amount of the prestrain was smaller than that of the strain at fracture, unless the change of the anisotropy due to the deformation was taken into consideration.

(Received May 29, 1968)

\section{1 緒言}

異方性材料の降伏条件式については, Hill, Dorn, Edelman ( ぞれの式を提案しているが，詳細な案験的検討は，ほ とんど行なわれていない。そこで，本報告では，これ らの式のらちで最も広く採用されている Hill の異方 性降伏条件式

$$
\begin{gathered}
F\left(\sigma_{y}-\sigma_{z}\right)^{2}+G\left(\sigma_{z}-\sigma_{x}\right)^{2}+H\left(\sigma_{x}-\sigma_{y}\right)^{2} \\
+2 L \tau_{y z}{ }^{2}+2 M \tau_{z x}{ }^{2}+2 N \tau_{x y}{ }^{2}=1
\end{gathered}
$$

をとり上げ，その実験的検討を行なった。まず単軸方 向に前ひずみを与えた黄銅板から，引張方向が前ひず み方向と種々の角度をなす引張試験片を製作し, その 実験結果から, Hill の異方性定数の前ひずみによる変 化を調べた。次に，これらの異方性定数を用いて計算 した降伏曲面を, 二軸引張試験片による実験結果と比 較した。また，単軸引張試験片に現われた「くびれ角」 の測定值と Hill の理論による計算値との比較も行な った.

* 原稿受理 昭和43年 5 月29日

** 正 会 員 東京工業大学精密工学研究所 東京都目黒区大岡山

*** 正会員 東京工業大学大学院 東京都目黒区大岡山
2 実 験

\section{$2 \cdot 1$ 異方性定数の決定}

厚さ $1 \mathrm{~mm}$ の黄銅板 $\left(\mathrm{BsP} 3-1 / 2 \mathrm{H}, 550^{\circ} \mathrm{C} 3\right.$ 時間焼

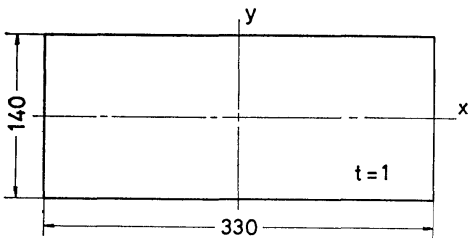

(a) Specımen I

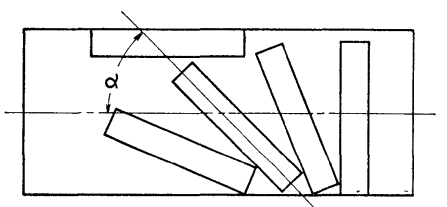

(b) Orientation of specimen II

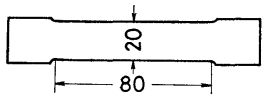

(c) Specimen II

Fig. 1. Tensile specimens. 
なまし）を用いて，Fig. 1 の(a)の試験片Ｉを作り， その $x$ 軸方向に種々の大きさ $(1,2,10 \%)$ の前ひ ずみを与えた後, その試験片から, Fig. 1 の (b) に示 すような板取りによって, 前ひずみ方向と引張方向と が，角度 $\alpha\left(\alpha=0 ， 22.5,45,67.5,90^{\circ}\right)$ をなすよ

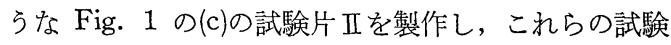
片IIの引張試験結果から, Hill の異方性定数を決定し た.これらの引張試験結果の一部を Fig. $2 \sim 4$ に示 してある. Fig. 2 は，初めに与えた前ひずみの大き さが10\%の場合について, 試験片 II の引張応力と引張 ひずみの関係を示したものであり, Fig. 3 は, Fig. 2 から同じ大きさの永久ひずみに対応する応力と試験方 向 $\alpha$ との関係を示したものである. また, Fig. 4 は, 試験方向 $\alpha$ とその方向の降伏応力（すなわち, 試験片

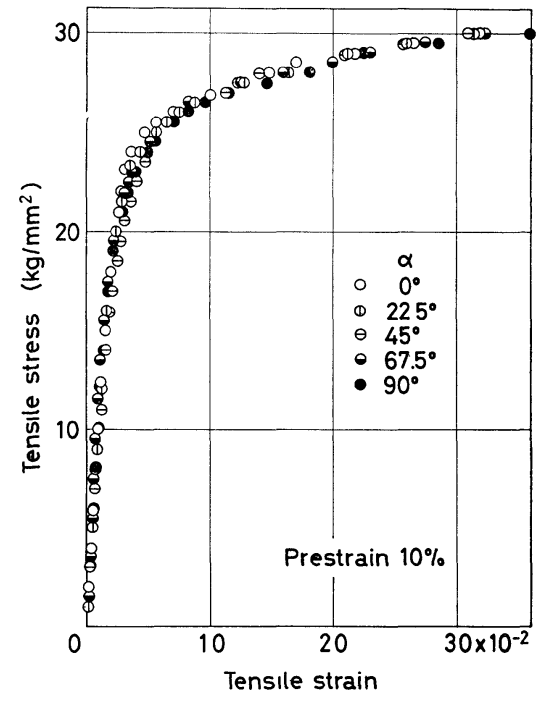

Fig. 2. Typical stress strain diagrams.

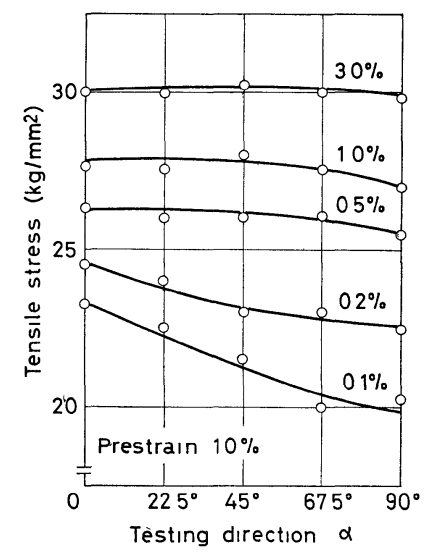

Fig. 3. Tensile stress corresponding to the various amount of plastic strain.

*1 降伏点は，002\%の大きさの永久ひずみに対応する応力と定義し た.

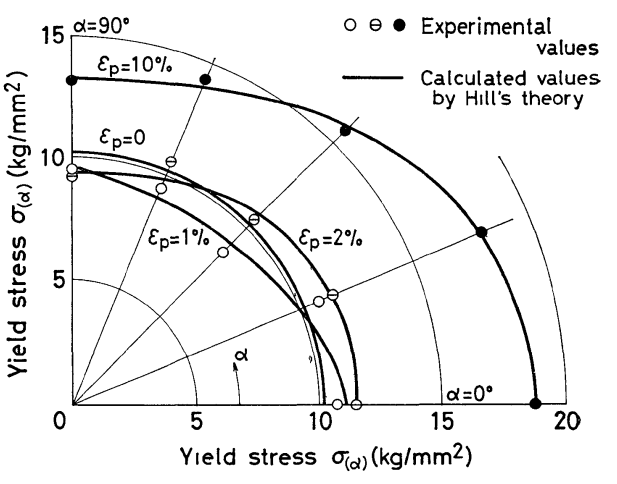

F1g. 4. Comparison of the uniaxial yield stress between the experimental and calculated values by Hill's theory.

III降伏時の応力） $\sigma_{(\alpha)}$ との関係をそれぞれの大きさ の前ひずみ $\varepsilon_{P}$ について，極座標方式によって示した ものである。

いま, 試験片 I の単軸引張の方向に $x$ 軸, それと直 角に板幅方向に $y$ 軸，板厚方向に $z$ 軸をとる. Fig. 1 の試験片 I の $x$ 軸方向と角度 $\alpha$ をなす方向での降伏応 力は $\sigma_{(\alpha)}$ であるから異方性の主軸（すなわち， $x$ 軸， $y$ 軸, $z$ 軸) に関する $\sigma_{(\alpha)}$ の成分は

$$
\begin{aligned}
& \sigma_{x}=\sigma_{(\alpha)} \cos ^{2} \alpha, \quad \sigma_{y}=\sigma_{(\alpha)} \sin ^{2} \alpha, \quad \sigma_{z}=0 \\
& \tau_{x y}=\sigma_{(\alpha)} \sin \alpha \cos \alpha, \quad \tau_{y z}=\tau_{z x}=0
\end{aligned}
$$

となる。(2)式を(1)式に代入すれば，

$$
\begin{aligned}
& (F+H) \sin ^{4} \alpha+(G+H) \cos ^{4} \alpha \\
& +2(N-H) \sin ^{2} \alpha \cos ^{2} \alpha=\sigma_{(\alpha)}^{-2}
\end{aligned}
$$

が得られる。したがって，3方向の $\sigma_{(\alpha)}$ を測定すれ ば，(3)式から $(F+H),(G+H),(N-H)$ の值を 定められるが，本実験では，精度向上のため， $\alpha=0$, $22.5,45,67.5,90^{\circ}$ 方向の降伏応力の值を用いて, 最小自乗法により, $(F+H),(G+H),(N-H)$ の値を計算した，Table I は，その結果を示したもの である。このようにして異方性定数の間の 3 個の関係

Tabel I. Relations between Hill's constants.

\begin{tabular}{c|c|c|c}
\hline $\begin{array}{c}\text { Prestrain } \\
(\%)\end{array}$ & $\begin{array}{c}F+H \\
\left(\times 10^{-3}\right)\end{array}$ & $\begin{array}{c}G+H \\
\left(\times 10^{-3}\right)\end{array}$ & $\begin{array}{c}N-H \\
\left(\times 10^{-3}\right)\end{array}$ \\
\hline 1 & 10.88 & 814 & 15.79 \\
2 & 11.47 & 7.77 & 7.47 \\
10 & 5.75 & 2.83 & 3.74 \\
\hline
\end{tabular}

式が得られる。 4 個の異方性定数 ( $F, G, H, N)$ の值を決定するのに必要な残り一つの関係式は, 次の よらにして得られる。すなわち，等方性材料では $x$ 軸

*2 試験片 I の $x$ 軸方向に $1 \%$ の前ひずみを与え応力をOまて除荷し たときの， $x$ 軸方向のひすみ $\varepsilon_{x}$ に対する $y$ 軸方向のひすみ $\varepsilon_{y}$ およびz軸方向のひすみ $\varepsilon_{z}$ の比すなわち $\varepsilon_{y} / \varepsilon_{x}$ と $\varepsilon_{z} / \varepsilon_{x}$ の值は, それぞれー0.45,一0.55であった. したがって, 実験に使用した材 料は，前ひすみを与える前の状態ては，等方性てあるとみなした. 
方向に単軸引張りの前ひずみを与えた場合には，異方 性は $x$ 軸の回りに回転対称となり, $y$ 軸方向と $z$ 軸方 向の前ひずみの大きさは等しくなるはずであるから， $y$ 軸方向の降伏応力と $z$ 軸方向の降伏応力は等しくな ければならない。したがって(1)式より

$$
H=\frac{1}{2 \sigma_{(0)}^{2}}(=G)
$$

が与えられる。(4)式を用いてHの值を決め, Table I の結果から $F, G, H$ の值を計算した結果が, Table II に示されている. Table II に示すように, 異方性 が $x$ 軸回りに回転対称であるための一つの必要条件 $H$ =Gは，ほぼ満たされている.

Table II. Values of Hill's constants.

\begin{tabular}{c|c|c|c|c}
\hline $\begin{array}{c}\text { Prestrain } \\
(\%)\end{array}$ & $\begin{array}{c}F \\
\left(\times 10^{-3}\right)\end{array}$ & $\begin{array}{c}G \\
\left(\times 10^{-3}\right)\end{array}$ & $\begin{array}{c}H \\
\left(\times 10^{-3}\right)\end{array}$ & $\begin{array}{c}N \\
\left(\times 10^{-3}\right)\end{array}$ \\
\hline 1 & 6.52 & 3.78 & 436 & 20.15 \\
2 & 766 & 396 & 381 & 11.29 \\
10 & 433 & 1.41 & 1.42 & 5.16 \\
\hline
\end{tabular}

\section{$2 \cdot 2$ 異方性降伏曲面の測定}

二軸引張状態で単軸方向の前ひずみを与えた後の降 伏曲面は，次のようにして実験的に定めた。すなわち， Fig. 1 の (a)の試験片 I と同じ材料で製作した二軸引 張試験片の $x$ 軸方向に，なずある大きさの引張前ひず み $(1 \%)$ を与え除荷した後, 応力比一定の経路 $\left(\sigma_{y}\right.$ $/ \sigma_{x}=1 / 9,1 / 4,5 / 14,1 / 2,2 / 3,1 / 1,3 / 2,2 / 1,4 / 1$, ）に沿って負荷し, そのときの降伏点を決めた。 次

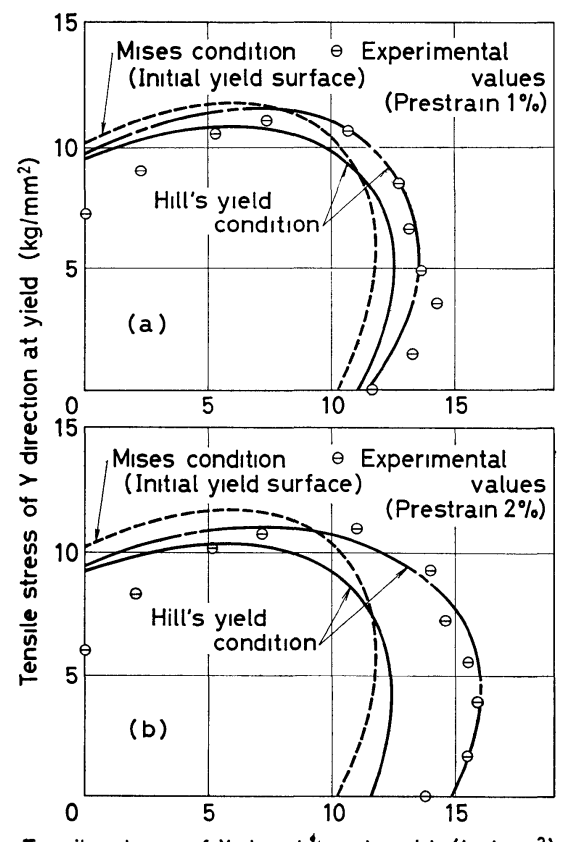

Tensile stress of $X$ direction at yield $\left(\mathrm{kg} / \mathrm{mm}^{2}\right)$

Fig. 5. Comparison of the yield surface between the experimental and calculated values by Hill's theory.
に， $x$ 軸方向に前よりも大きな前ひずみ ( $2 \%)$ を与 え, 前と同様の方法で, そのときの降伏点を定めた. この実験方法については, すでに報告してある. 得ら れた実験値を Fig. 5 に示した.

\section{3 実験結果の考察と Hill の理論の検討}

\section{$3 \cdot 1$ 異方性定数の変化}

異方性降伏条件式(1)は, 平面応力状態では,

$$
\left(\sigma_{x}-\sigma_{y}\right)^{2}+\frac{F}{H} \sigma_{y}^{2}+\frac{G}{H} \sigma_{x}^{2}+2 \frac{N}{H} \tau_{x y}{ }^{2}=\frac{1}{H}
$$

となる.いま

$$
\frac{F}{H}=\frac{G}{H}=\frac{N}{3 H}=1
$$

が成立する場合には(5)式は,

$$
\left(\sigma_{x}-\sigma_{y}\right)^{2}+\sigma_{y}^{2}+\sigma_{x}^{2}+6 \tau_{x y}{ }^{2}=2 \sigma_{(0)}^{2}
$$

となり, 等方性材料の降伏条件式の一つである Mises の式と一致する.したがって $F / H, G / H$ ， および $N /(3 H)$ の值を 1 と比較すれば，与えた前ひずみに よる異方性定数の変化がわかる. Table III に $F / H$, $G / H, N /(3 H)$ の值と与えた前ひずみの大きさとの

Table III. Change of Hill's constants by the amount of prestrain.

\begin{tabular}{c|c|l|l}
\hline $\begin{array}{c}\text { Prestrain } \\
(\%)\end{array}$ & $\frac{F}{H}$ & $\frac{G}{H}$ & $\frac{N}{3 H}$ \\
\hline 1 & 1.50 & 0.867 & 1.54 \\
2 & 2.01 & 1.04 & 0986 \\
10 & 3.04 & 0.993 & 1.21 \\
\hline
\end{tabular}

関伱を示した。この結果から, 異方性定数の比 $F / H$, $G / H, N /(3 H)$ の值と前ひずみの大きさとの関係に ついて次のことがわかる。すで述べたよらに $G / H$ の值はほぼ 1 飞等しい. $N /(3 H)$ の值はほぼ 1.0 から 1.5 の間を変化している. $F / H$ の值は, 与兄た前ひ ずみの量が大きくなるにつれて増加する。したがって，

$$
\frac{G}{H}=1, \frac{F}{H}=a, \frac{N}{3 H}=b
$$

と扰けば，単軸引張りによっで前ひずみを与充た場合 の降伏条件は, 平面応力状態では二つの異方性定数 $a$ および $b$ を用いて

$$
\left(\sigma_{x}-\sigma_{y}\right)^{2}+a \sigma_{y}^{2}+\sigma_{x}^{2}+6 b \tau_{x y}{ }^{2}=2 \sigma_{(0)}^{2}
$$

と書けることになる。ここで定数 $a$ は前ひずみの量と ともに增加するが，定数 bは与える前ひずみの大きさ によって，約0.98から1.54の間を变化する.

\section{$3 \cdot 2$ 試験片 II の応力ーひずみ関係}

Fig. 2 に示した各試験方向の応力ーひずみ関係を比 較すると, 同一の大きさの引張応力に対する引張ひず みの大きさは, 降伏後に扔いては, 引張方向と前ひず 及方向とのなす角度 $\alpha$ が大きなるにつれて大きくな っている.すなわち, 前ひずみ值角な方向のほうが 伸びやすい，しかし，引張ひずみの大きさが約 $3 \%$ 以 
上になると各方向の応力ーひずみ線図は，一つの曲線 に収束してくる傾向がある.

また，Fig. 3 に示すよらに，同一の大きさの永久 ひずみに対応する応力の大きさは，永久ひずみの值が 小さい範囲では, 試験方向が $\alpha=90^{\circ}$ の場合より, $\alpha$ $=0^{\circ}$ の場合のほうが大きくなるが，永久ひずみの值 が大きくなるにつれて対応する各方向の応力の大きさ は，同一の值に近づく傾向がある.

これらの結果は，すでに報告した圧延材の引張試験 結果と非常に異なっている.

Fig. 4 には， $\sigma_{(\alpha)}$ の実験值のほかに，それらの計 算值を(3)式と Table I から求め実線で示してある. 試験片Iに与える前ひずみの大きさが，あまり大きく ない場合は, 与えた前ひずみと直角方向の降伏応力 $\sigma_{(90)}$ は，最初の降伏応力より小さくなり， いわゆる 交差効果を示すが，与える前ひずみの大きさが大きく なると， $\sigma_{(90)}$ は最初の降伏応力よりも大きくなり, 交差効果は示さない.

\section{$3 \cdot 3$ Hill の降伏条件の検討}

従来, Fig. 4 のような比較によって降伏条件の妥 当性を論じたものがあるが，降伏条件は組合せ応力試 験によって検討しなければならない。

さて, Table II の異方性定数の值を用いると， (5) 式から Hill の降伏曲面が計算できる. Fig. 5 に，こ れらの計算值（図に実線で示した）と実験值との比較 を示した。図から明らかなよらに，実験值と計算值の 不一致の程度は, 単軸方向に与えた前ひずみの大きさ が大きくなるにつれて顕著になる．なお，前ひずみ方 向の降伏応力 $\sigma_{(0)}$ の值としては前ひずみを与えたと きの応力の值 $\sigma_{(0)}^{P}$ と前ひずみを与えた後, 同じ経路に 沿って除荷し再負荷したときの応力ーひずみ線図から 定められる降伏点の值 $\sigma_{(0)}^{R}$ の二つが考学られる. 前ひ ずみを与えた後の降伏曲面を決めるといら点から考劣 れば， $\sigma_{(0)}$ の值として， $\sigma_{(0)}^{R}$ を用いるほうが合理的で あるが， $\sigma_{(0)}^{P}$ は与えた前ひずみの程度を表わすとも考 えられるから, 実用的には $\sigma_{(0)}^{P}$ を $\sigma_{(0)}$ とする場合も あろう. 本実験の場合, 与える前ひずみの大きさが大 きくなるにつれて, Fig. 6 に示すように， $\sigma_{(0)}^{P}$ と $\sigma_{(0)}^{R}$ の值は一致しなくなり，一般に $\sigma_{(0)}^{P}$ のほうが $\sigma_{(0)}^{R}$ よ り低くなった，試験片結果を用いて異方性定数を 定めたことは， $\sigma_{(0)}$ の值として $\sigma_{(0)}^{R}$ の值を採用したこ とになるから，前ひずみを与えた点近傍では，降伏曲 面の計算値が実験值より小さくなったと考えられる. も乙 $\sigma_{(0)}^{P}$ を $\sigma_{(0)}$ の值として異方性定数を定めた場合 には, Fig. 5 に一点鎖線で示すよらな計算值が得ら れ, 計算值は実験值にかなり近くなったが異方性定数 は, 回転異方性の一つの必要条件である(4)式を満足し ないといら矛盾を生じた。

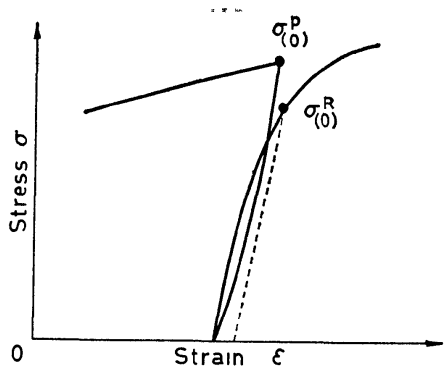

Fig. 6. Yield point in the prestraining direction.

\section{$3 \cdot 4$ くびれ角の検討}

Hillによれば, 異方性のある引張試験片に現われる 「くびれ角」( $\beta$ ) は,

$$
a \tan ^{2} \beta+b \tan \beta-c=0
$$

で与えられる.ここで

$$
\begin{aligned}
a & =H+\sin ^{2} \alpha \cos ^{2} \alpha[(N-F-2 H)+(N-G-2 H)] \\
b & =2 \sin \alpha \cos \alpha\left[(N-F-2 H) \sin ^{2} \alpha\right. \\
& \left.-(N-G-2 H) \cos ^{2} \alpha\right] \\
c & =F \sin ^{2} \alpha+G \cos ^{2} \alpha+H \\
& +\sin ^{2} \alpha \cos ^{2} \alpha[(N-F-2 H)+(N-G-2 H)] \\
& =\sigma_{(\alpha)}^{-2}
\end{aligned}
$$

である。

異方性定数の値に Table II の結果を用いて，(10)式

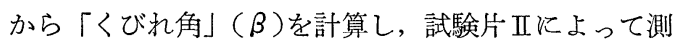
定したそれらの実験值との比較を Fig. 7 に示した. これらは試験片Iに与えた前ひずみの大きさが，それ ぞれ $2 \%$ と10\%の場合のものである. (10)式から明らか なよらに，「くびれ角」には正負二つの值があるので, Fig. 7 には，これらを区別して示してある(「くびれ 角」は Fig. 8 の矢印の方を正とする). これらの図 に示すように，各試験方向に関して，「くびれ角」の 計算值は，かなり変化するが，実験值は注ぼ一定の值 $\left(60 \sim 65^{\circ}\right)$ を示している.この違いは，(10)式に用いた

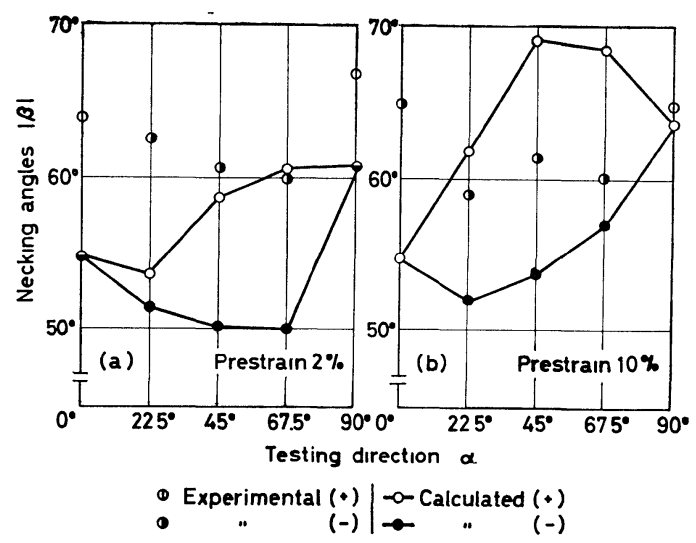

Fig. 7. Comparison of the necking angle between the experimental and calculated values by Hill's theory. 


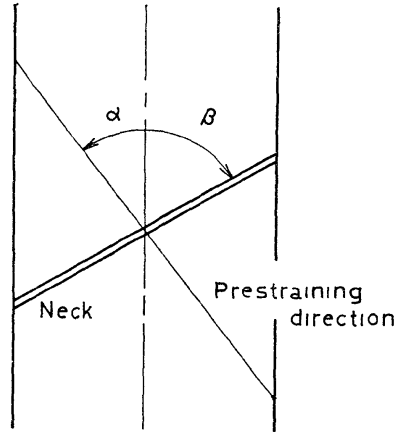

F1g. 8. Necking angle.

異方性定数の值に関係があると考穴られる。すなおち 「くびれ角」の計算には，与兄た前ひずみ状態におけ る異方性定数を用いた。しかし試験片正に「くびれ」 が発生するまでには，午の試験片はさらに引張方向に かなりの変形（約 $30 \%$ を艺てているから，「くびれ角」 の計算には，「くびれ」発生直前の異方性定数を用い なければならない，ところが，Hillの理論では，ひず み履歴による影響は考慮されていないので，くびれ発 生直前の異方性定数を計算することができない。した がって, 試験片が「くびれ」発生まで炕きく変形す る場合，(10)式からは正確に「くびれ角」を計算できな い。また，すで述べたように試験片は「くびれ」発 生までに大きく変形しているので, 試験片の最初の暴 方性は, 単軸引張りによる異方性に比べて, 無視でき る程度になっているはずである。したがって，各試験 方向の「くびれ」発生直前における異方性には潘とん ぞ羑がなく，「くびれ角」にも，午の差が現われなか ったものと考党られる.

\section{4 結 言}

単軸方向に前ひずみを与えた黄銅板から，前ひずみ 方向と引張方向とが種々の角度をなす単軸引張試験片
を製作し，その試験結果から前ひずみによる Hill の 異方性定数の变化を調べた。次に, これらの異方性定 数を用いて計算した降伏曲面を, 二軸引張試験片によ るとの実験值と比較し，実験に使用した材料について は次のことがわかった。

（1）単軸引張りによって異方性を与兄た場合, Hill の異方性降伏条件式は, 平面応力状態では近似的に次 式

$$
\left(\sigma_{x}-\sigma_{y}\right)^{2}+a \sigma_{y}{ }^{2}+\sigma_{x}{ }^{2}+6 b \tau_{x y}{ }^{2}=2 \sigma_{(0)}^{2}
$$

で表わせた。 ここで定数 $a$ は前ひずみの量とともに増 加し, 定数bは約0.98から1.54の間を変化した。 また $\sigma_{(0)}$ は前ひずみを与兄た方向の降伏応力である.

(2) Hill の異方性降伏曲面の計算値と実験值との間 には，かなりの差があった。しかし，前ひずみを与兄 たときの伈力の値を用いて異方性定数を定めると，そ の差は縮京った。

(3) Hill の「くびれ角」の計算式は, 初めの異方性 がきわめて大きく,くびれ発生まで吝まり変形しな い場合にしか適用できないよらであった。

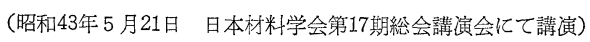

\section{参考文 献}

1) Hill, R., Proc. Roy. Soc. London. Ser. A., 193, 281 (1948).

2) Dorn, J. E., J. App1. Phys., 20, 15 (1949).

3) Edelman, F., and D. C. Drucker, J. Franklin Inst. 251, 581 (1951).

4) Yoshımura, Y., Aero. Res Inst. Univ. Tokyo Report No. 349 (1959).

5) Svensson, N. L., J. Mech. Engng. Sci., 8-2, 162 (1966).

6) 白鳥英亮, 池上皓三, 材料, 16, 433 (1967).

7) 白鳥英亮, 池上皓三, 風間慶一, 日本機械学会論文集, 35, 271 (1969) 掲載予定. 